\title{
Unconscious decisions causing a failure condition of the 19th century brick ceiling
}

\author{
Dariusz Bajno, Agnieszka Grzybowska* and Rafat Tews \\ University of Science and Technology, Faculty of Civil and Environmental Engineering and \\ Architecture, Department of Building Structures, Poland
}

\begin{abstract}
The article describes a hazard caused by deformation of a brick vault located under the dungeons of the gate tower of Zamek Górny in Opole at the turn of the $13^{\text {th }}$ and the $14^{\text {th }}$ centuries, which was used as a school building until 2017. The hazard identified in 2013 was found on the ground level of the building in a communication route of the heavy traffic load. Visual inspections and tests have demonstrated that the existing situation was caused by civil works performed at the dungeon level nearly 6 years earlier due to an unconsidered decision on removing debris and a backfill which filled entirely the lower tower storeys. The above actions resulted in removal of the base of the floor 'laid on the ground' in the 19th century [2][4]. In this article, an analysis was carried out to verify possibilities of unbelievable strength of the artificially formed flat vault, which was previously the floor supported on a debris and sand base.
\end{abstract}

\section{Introduction}

The subject of the article is a gate building of a traditional masonry structure constituting an element of the defence system of the Piast castle from the turn of the $13^{\text {th }}$ and the 14 th centuries. The golden age of these buildings passed when they were stopped to be used as fortifications, i.e. when completely new battle and war practices were introduced and the weapons changed. Another age has come, the age of oblivion and natural degradation resulting from negligence in proper maintenance, as well as well-thought and rash invasive operations, which partially or completely changed the intended use of the mentioned structures. Nowadays, we would call it a change of a usage method [1][2][4]. Due to many years of omissions relating to the improper maintenance of these buildings and structures, some of them have fully degraded so in much cases they just vanished from our landscape or were simply demolished [1]. Zamek Górny in Opole was affected by similar factors which brought it to the current condition. Its remaining parts were transformed into facilities intended for other purposes, in this case - educational. In 1829, a decision was made to expand the building. In 1831, the castle ceased to be a venue for teaching purposes as a new edifice was opened with an auditorium and 7 classrooms (the building was elevated with one storey in 1909-10). Part of the tower was renovated as well and the school was expanded in 1859 to include a gymnasium. In 1937, a side wing of the edifice

\footnotetext{
${ }^{*}$ Corresponding author: grzybowska.utp@gmail.com
} 
was built where once stood the defensive wall. This part was integrated with the defensive wall whose aboveground part was dismantled. When Opole was taken by the Red Army, the buildings were converted into the front-line hospital which saved them from further degradation as it was the case for the majority of city centre buildings. Today, the school continues the tradition of the State Industrial School established on 15 September 1947 (being the only host of the buildings since 1948) and the tradition of the 1st National Secondary School and High School for Boys. The name of the Mechanical School has been used since 1975 [2][4].

a)

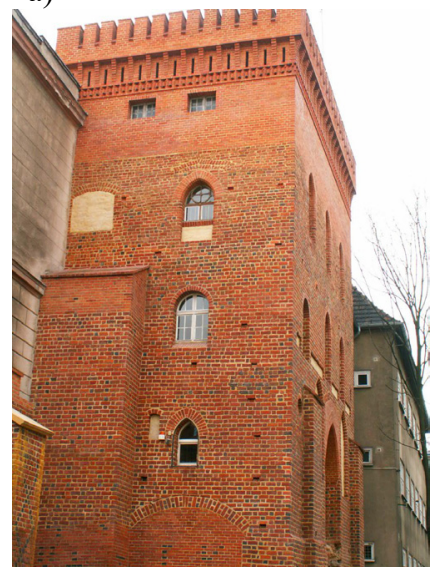

b)

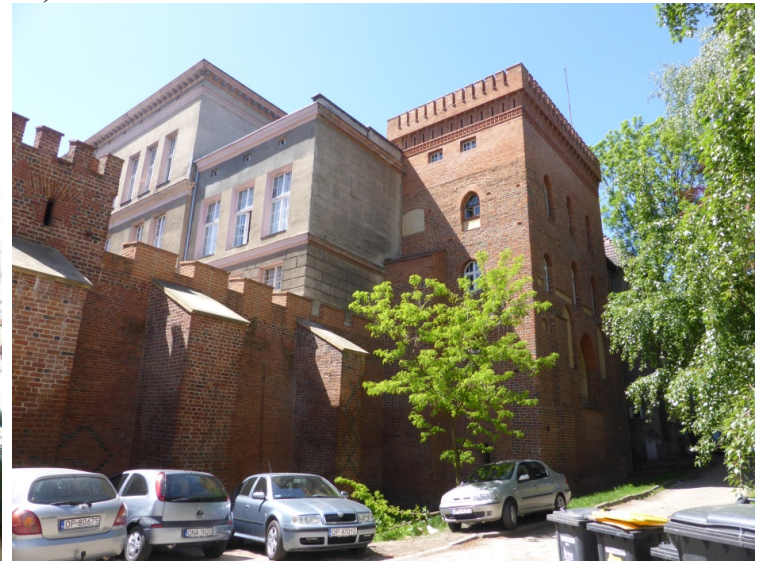

Fig. 1. The gate tower: a) the view of the building concerned, b) the view of all the buildings

In September 2013, the deformations of the floor fragment in the 'passage' between the main school building and the physics educational building (the gate access level - Fig. 2a) were observed, i.e. in the place constituting the element of the communication route of the variable load which raised a building owner's concern about the use safety.

a)

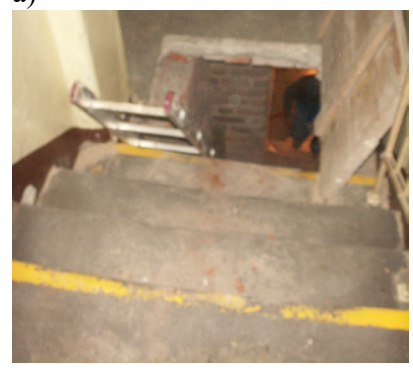

b)

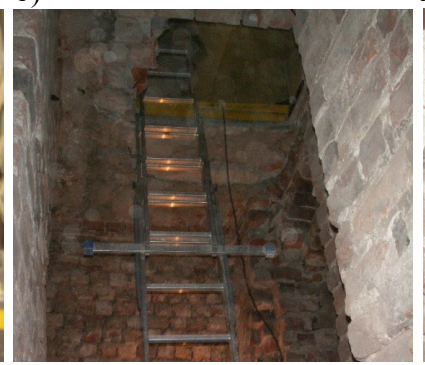

c)

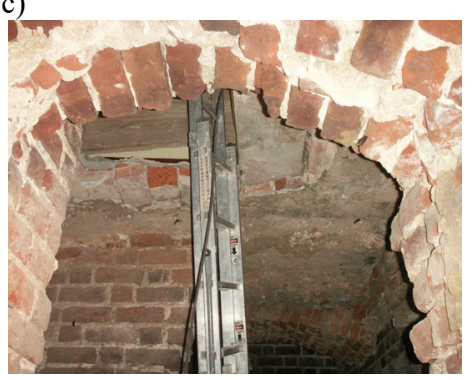


d)

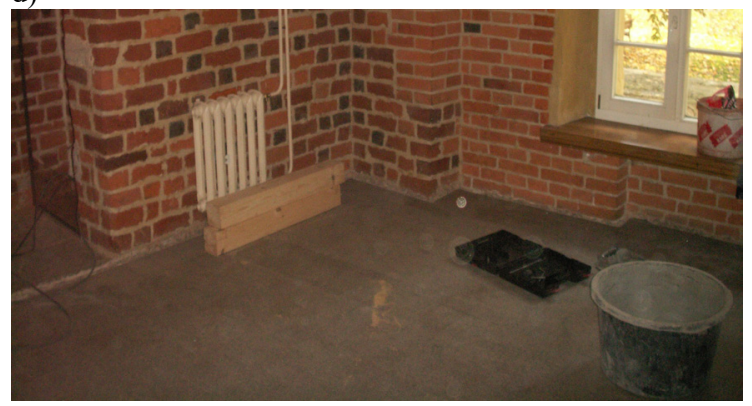

e)

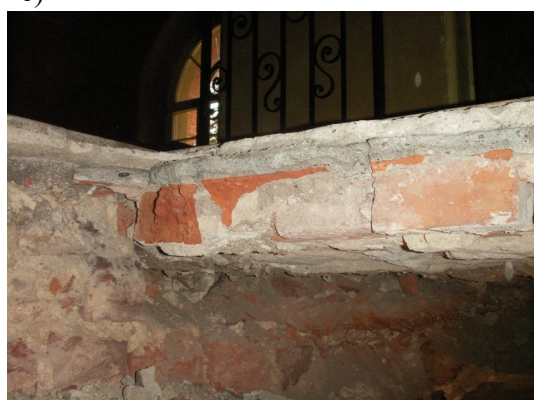

Fig. 2. Location of damage: a) in the passage between the buildings, b) in the passage between the buildings, c) bottom view, d) location of the second damage, e) ceiling layer exposure

The purpose of the article is to verify possibilities of unbelievable strength of the artificially formed flat vault, which was previously the floor supported on a debris and sand base.

\section{Material and methods}

\subsection{Actual state description}

Visual inspections carried out in September 2013 revealed damage to the ceiling structure which made it necessary to expose the site in the days that followed [Fig. 2e]. The examination demonstrated that the structure consisted only of a flat fragment of a ceramic brick board without any reinforcement and not connected with the remaining basement vaults. Probably, it was made in the 19th century using full ceramic bricks laid on the debris and sand base with with gaps filled with mortar containing lime and cement [2]. Without reinforcement, this board could not have been a load-bearing component of a single-span ceiling, even at such a short span of $\sim 1.25 \mathrm{~m}$. As it was mentioned above, this is a component subject to a variable load, since it is located in a place where students move between two educational buildings of the Mechanical School. The location of damaged ceiling fragments is shown in Fig. 3.

a)

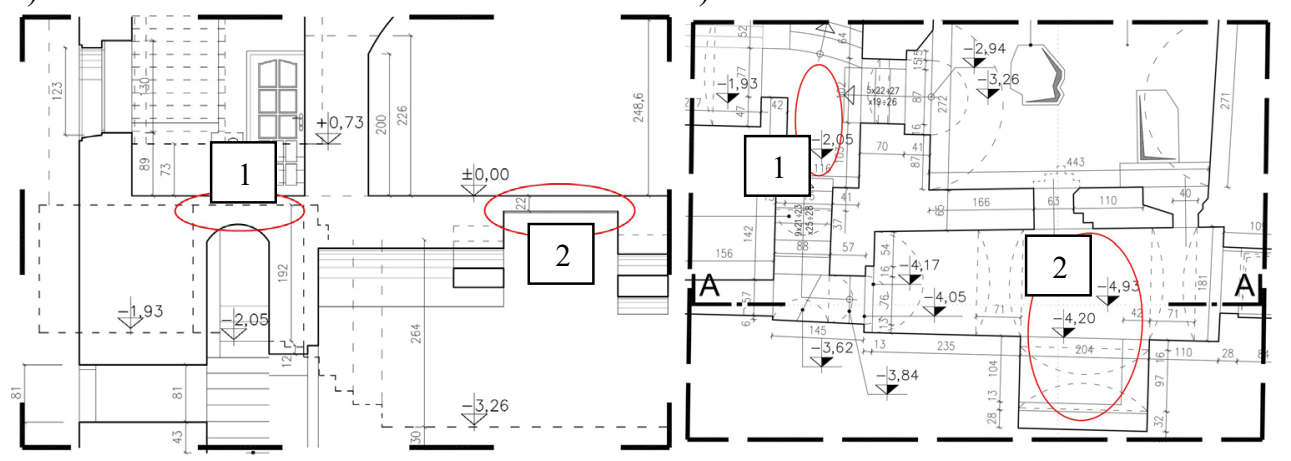

Fig. 3. Location of damage 1 and 2 (marked with red ellipses): a) A-A vertical section, b) basement floor plan

Based on the exposure, it was found that the floor had been made with an assumption that it would serve as a flat girder laid on the 'ground' with its entire surface. After 
selecting a backfill for the 'dungeons' of the tower, the base of the above-mentioned floor and the floor of the adjacent room (basements - the dungeons were filled with debris and sand) was also removed. The static scheme of the board leaning against the base (being a fill) with its entire surface changed to a board structure supported on two edges only. An interesting fact is that the building was used for about 6 years without any symptoms of its deformation or risk. When reviewing the basement units, a disturbing situation was discovered in the adjacent room (identical to that described above - Fig. 2d), however, the builder had applied a provisional structure to protect the ceiling/floor by covering single bars and fragments of fireboards. In this case, the ceiling span was much higher, so was the risk of losing its stability. That fragment of the ceiling, which had been used previously as a floor 'laid on the ground', did not show any deformation. A construction disaster was prevented by introducing provisional ceiling shoring (reinforced in 2013) and due to the fact that this fragment of the ceiling was outside the area of heavy traffic [Fig. 2d].

\subsection{Static and strength analysis}

A structure model (the ceiling of the intensively used passage between the educational building) was created in Autodesk Structural Analysis Professional 2018. The following load was taken for analysis purposes:

- dead load which was defined in the software by imposing proper thickness and material parameters to the individual panels. Furthermore, load by finishing layers, i.e. cement mortar and stone slabs, was taken into account in this group $\left(1.68 \mathrm{kN} / \mathrm{m}^{2}\right)$;

- variable load, taking the C5 use class (generally accessible surfaces, e.g. in public facilities) of $5 \mathrm{kN} / \mathrm{m}^{2}$. However, when analysing damage 1 located in the intensively used passage between the buildings, this load was increased by introducing an additional dynamic factor of 1.5 which considers students jumping onto this slab (from the stairs nearby).

The authors did not carry out strength tests of bricks as none of them shown any traces of damage. Estimated weights and strength of bricks used from the 14th to the 19th century are given in [3]. On the basis of the above and many years of experience (including own research) with new and medieval masonry structures, the compressive strength of bricks for the considered case was assumed to be $52 \mathrm{kG} / \mathrm{cm}^{2}$ (approx. $5.0 \mathrm{MPa}$ ) with a longitudinal stiffness module of $5000 \mathrm{MPa}$. In order to describe the vault structure and adjacent walls, a homogeneous coating model was applied, i.e. a macromodel (Fig. 4) which gives certain approximation of the problem necessary to clarify the operating principle of the vault using an equivalent material model $[3,7]$. Proper releases were applied in the place of connections of the mentioned 'vault' with the walls, which was reflected by hinges. Moreover, an automatic finite element mesh was generated with the Coon's method. 
a)

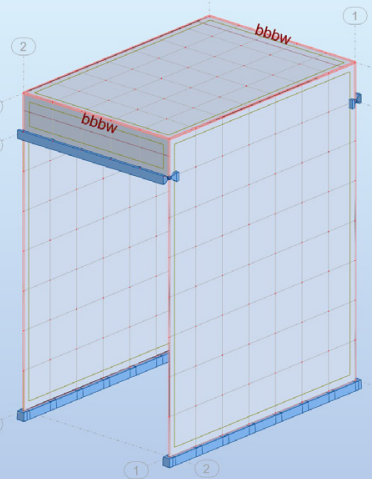

b)

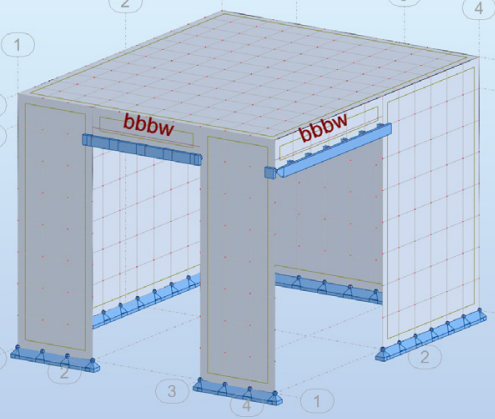

Fig. 4. View of vault models: a) corridor (damage 1 as per Fig. 3), b) second rooms (damage 2 as per Fig. 3)

a)

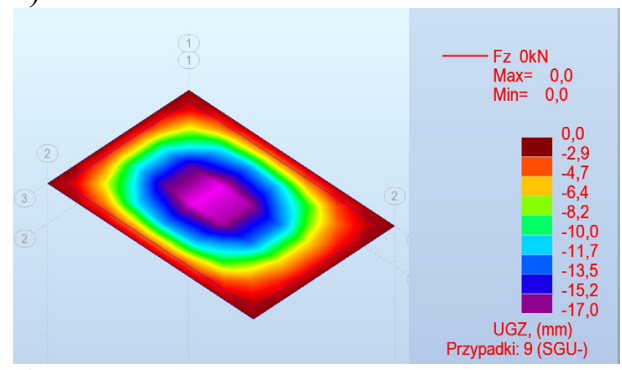

c)

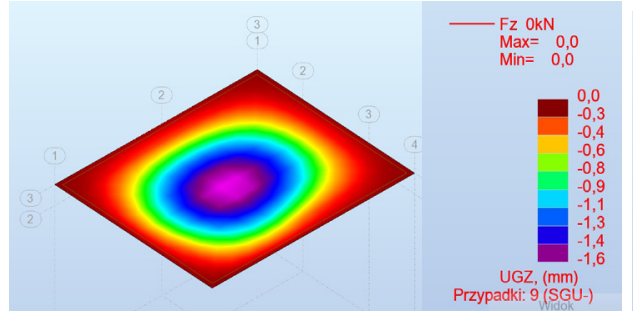

b)

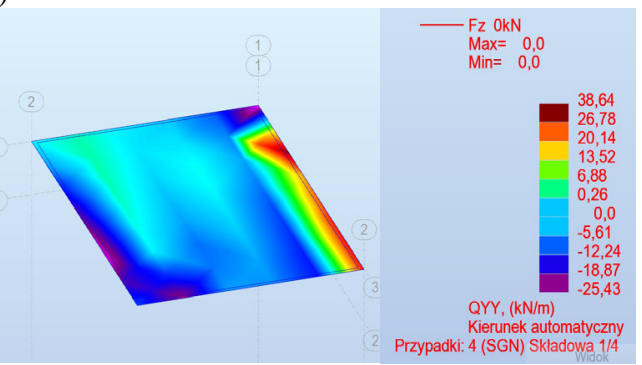

d)

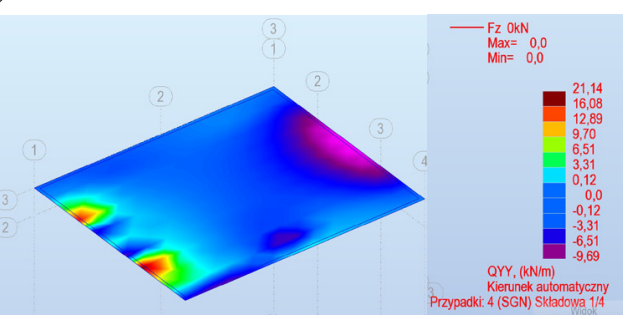

Fig. 5. View of the model: a) global displacement relative to the $Z$ axis defined for damage 1 , b) $\tau_{y}$ shearing forces defined for damage 1 , c) global displacement relative to the $\mathrm{Z}$ axis defined for damage 2 , d) $\tau_{\mathrm{y}}$ shearing forces defined for damage 2

A certain analogy can be found in the analysed case in the context of Kleinesche Decke ceiling or Pomorze-type ceiling [5,6], whereas, it should be emphasised that the considered 'vault' has not been reinforced. A vertical weld cannot carry tensile stresses which take extreme values in the point of maximum bending (Fig. 5a, c) and excessive shearing forces in the wall interface (Fig. 5b, d).

\subsection{Temporary solutions}

Due to the condition of the basement (dungeon) ceiling, it was necessary to immediate exclude it out of use, i.e. to protect it from access by any persons and make a temporary reinforcement and finally to consult the problem with the Opole Province Monument 
Conservatory. An explicit statement was made that the described fragments of the ceiling above the 'dungeons' - not serving as vaults - are not self-bearing components and have to be urgently reinforced or replaced by new ones. Further use of the same in an unaltered condition posed a risk of a construction disaster and a direct threat to life and health of building users. In September 2013, a temporary support of the ceiling was designed and made to operate until its final reinforcement. This has not been changed to date [Fig. 6b]. Currently, the target solution is being developed on the basis of a construction design, so actually there is no final reinforcement made in consultation with the Opole Province Monument.

a)

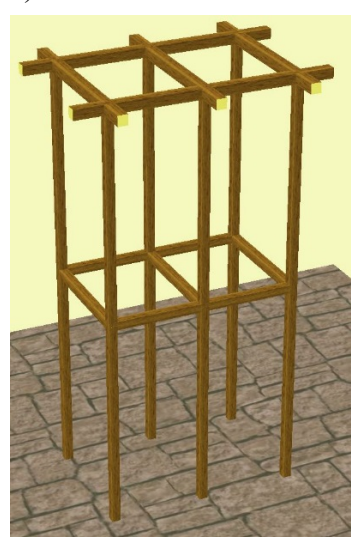

d) b)

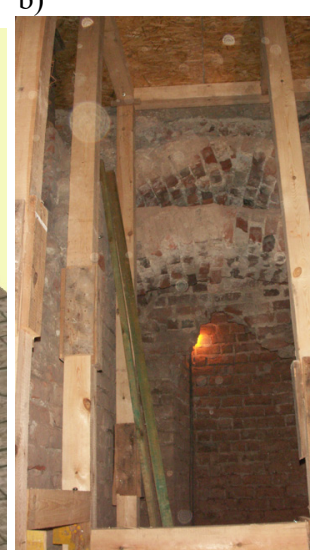

c)

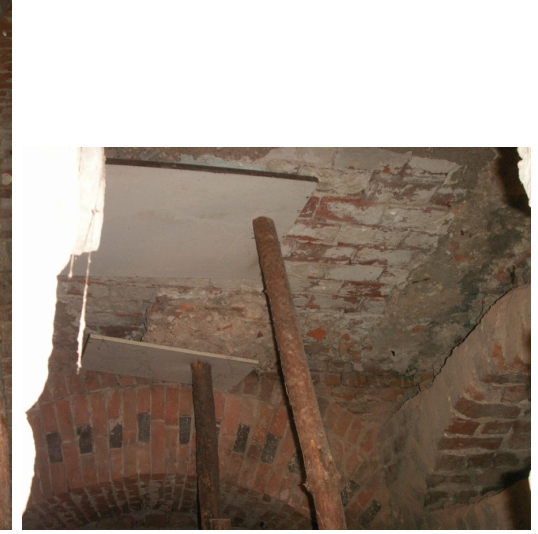

e)
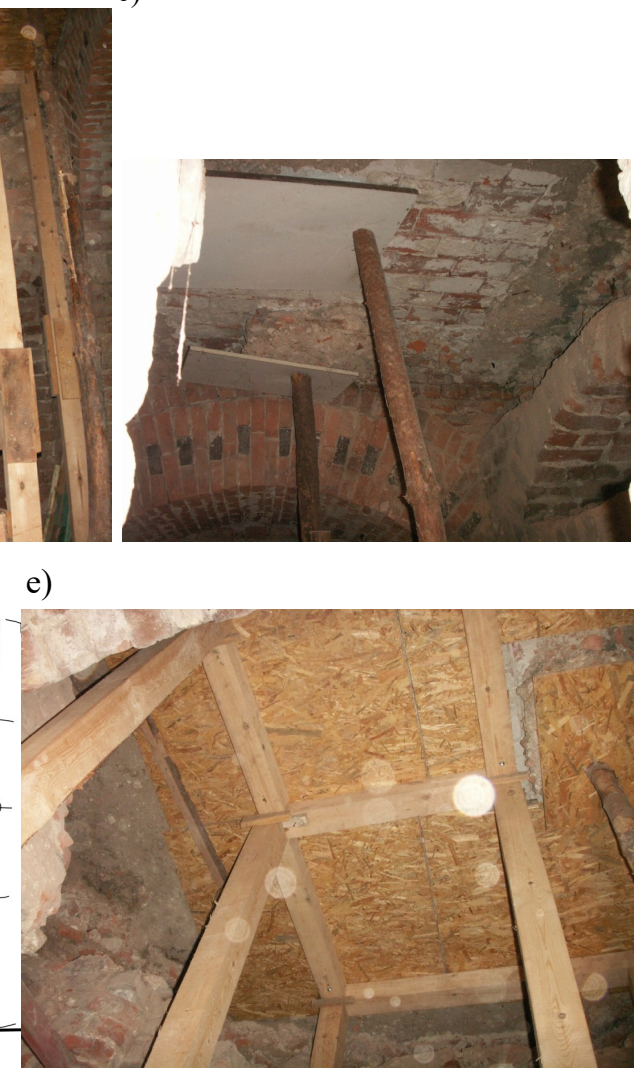

Fig. 4. Temporary supports: a) visualisation, b) view, c) inserted by the contractor in the place of 2, d) location, e) view

Both the walls and the remaining ceiling of the gate tower did not show deformation or any other symptoms indicating a threat posed by any of the structural members during the tests. Due to classes in the tower rooms, the wooden ceiling was not exposed. This is now carried out as part of its renovation and adaptation of the rooms for exhibition purposes.

Signs of uneven subsidence of the tower or the adjacent educational building were not found either. During the stay on the premises, only a cursory examination of wall moistness was carried out due to communication difficulties in such limited space and poor visibility.

Apart from dampness in the lowest part of the adjacent educational building, no signs of deformation, including cracking or fractures, were found. The technical condition of the underground part of the above-mentioned building is to be considered satisfactory in terms of its construction properties. 


\section{Conclusions}

The condition of the ceiling, in particular 'vaults' intensively used by the students, indicated the necessity to prepare a work covering static and strength calculations and propositions of temporary reinforcements. In the existing buildings, work of a construction engineer is not limited to the development of a project and acquisition of relevant decisions [1]. It must be continued throughout all repair and reinforcement periods, etc., and after completion of the same for further observation purposes. The case described herein indicates a risk situation revealed after a few years following an unjustified and irresponsible decision on removing debris accumulated in the underground rooms of the gate tower. The mentioned ceiling fragments have fulfilled their roles for a couple of years against the statics and material strength principles, where it became impossible to develop justified calculation models. The image of damages which occurred in the considered ceiling does not differ from the expected one - resulting from static calculations. Something that was impossible became real in a completely utilised facility. How many such cases we may encounter in our reality and discover in extreme situations which are or will be the outcome of unconsidered decisions or decisions resulting from the ignorance of persons responsible for proper maintenance or assessment of the technical condition of buildings? The ceilings described in this article were secured in time, however, it is difficult to explain why they did not cause any problems for a previous years.

\section{References}

1. Bajno D. „Rewitalizacja konstrukcji w obiektach budowlanych”. UTP Bydgoszcz 2013.

2. Bajno D. Opinia techniczna dot. ustalenia przyczyn uszkodzenia stropu nad "lochami" Wieży Zamku Górnego Zespołu Szkół Mechanicznych w Opolu przy ul. E. Osmańczyka oraz wskazanie sposobu/sposobów zabezpieczenia tego fragmentu budynku. Opole 2013 r.

3. Janowski Zbigniew, Hojdys Łukasz, Krajewski Piotr. 2015. „Sklepienia murowane klasyfikacja, ocena stanu technicznego i nośności, sposoby naprawy”. XXX Jubileuszowe Ogólnopolskie w Warsztaty Pracy Projektanta Konstrukcji.

4. Piecuch K., Bajno D. Projekt przebudowy wieży bramnej Zamku Górnego w Opolu. Opole 2014 r.

5. Ahnert R., Krause K. H.: Typische Baukonstruktionen von 1860 bis 1960 . Verlag für Bauwesen. Bauverlag, Berlin 1991.

6. Borusiewicz W.: Konserwacja zabytków budownictwa murowanego. Arkady, Warszawa 1985.

7. Żenczykowski W.: Budownictwo ogólne. Tom 2/1 i 2/2 - Elementy i konstrukcje budowlane. Arkady, Warszawa 1990. 